\title{
A review on foot and mouth disease in dairy animals, etiology, pathogenesis and clinical findings
}

\author{
Abdullah Azeem ${ }^{1 *}$, Immad Rashid ${ }^{1}$, Muhammad Muzzammil Hassan², \\ Muhammad Asad ${ }^{3}$, Ghazala Kaukab ${ }^{3}$, Amna Tehseen ${ }^{4}$ and Sabita \\ Aamir $^{3}$ \\ 1. Department of clinical medicine and surgery, University of Agriculture Faisalabad-Pakistan \\ 2. Department of Theriogenology, University of Agriculture Faisalabad-Pakistan \\ 3. Department of Zoology, Government College University Faisalabad-Pakistan \\ 4. Department of Zoology, Islamia University Bahawalpur-Pakistan \\ *Corresponding author's email:uaf2034@gmail.com
}

Citation

Abdullah Azeem Immad Rashid, Muhammad Muzzammil Hassan, Muhammad Asad, Ghazala Kaukab, Amna Tehseen and Sabita Aamir. A review on foot and mouth disease in dairy animals, etiology, pathogenesis and clinical findings. Pure and Applied Biology. Vol. 9, Issue 1, pp821-832. http://dx.doi.org/10.19045/bspab.2020.90088

Received: 08/09/2019

Revised: $17 / 12 / 2019$

Accepted: 23/12/2019

Online First: 01/01/2020

\section{Abstract}

Foot-and-mouth disease (FMD) is an extremely contagious disease of angulated animals and in livestock, it is an important pathogen more than 120 years after it was recognized. The virus of this disease belong to a genus Aphthovirus of the family picornaviridae and present as seven serotypes $\mathrm{C}$, O, A, SAT1, SAT2, SAT3, and Asia1. Transmission of this disease occurs by direct and indirect contact, ingestion and by aerosols. The best multiplication sites of this virus are oral cavity, udder, heart, feet, and oro-pharynx. Specific, sensitive and quick diagnostic tools are required for effective control of this disease. FMD causes fever, salivation, anorexia and vesicular eruption on teats, feet, and mouth. In FMDV (Foot and Mouth disease Virus) endemic areas, annual production losses and vaccination estimated US\$6.5-US\$21 billion. Currently, the techniques which are used for diagnosis of FMD are Sandwich-ELISA (S-ELISA), Virus Isolation (VI), indirect ELISA (DIVA), real timePCR and Liquid-Phase Blocking ELISA (LPBE) can be used for recognition of antibody against nonstructural proteins. The techniques which are used for quick and specific detection of FMDV are microarray and recombinant antigen-based detection, biosensor, Nucleotide sequencing, phage display and nucleic-acid-based diagnostic for serotyping. This review provides information about the FMD in Pakistan as many cases are reported in Pakistan and lead to morbidity and mortality of many animals. This review helps the reader to handle the cases practically in the field and helps the researchers to analyze the comprehensive picture of the FMD and in future researchers try to minimize such cases after reading this in Pakistan.

Keywords: Contagious; Diagnosis; Economic; Picornaviridae

\section{Introduction}

FMD is a major health problem of animals in all over the world [1]. It is the contagious TAD (transboundary animal disease) affecting the cloven-hoofed animals of wildlife and domesticated. Goats, sheep, cattle, pigs, and buffalo are vulnerable species of domesticated animals. 
Aphthovirus is an RNA virus that has 7 different serotypes such as C, O, A, SAT1, SAT2, SAT3, and Asia1 as well as over 60 subtypes. There are 60 copies of structural proteins present in the capsid of FMDV. These proteins are VP2, VP3, VP1 and there are 8 nonstructural protein $(3 \mathrm{~A}, 3 \mathrm{~B}, 3 \mathrm{C}$, L, 2A, 2B, 2C and 3D) [2, 3]. The virus of this disease is also called foot and mouth disease virus. This disease is spread throughout the world but most affected regions are Africa, Asia, and the Middle East. FMD free countries are Australia, Japan and New Zealand [4]. The main route of transmission in ruminants is inhalation of droplets but inoculation with contaminated vaccines, ingestion of infected feed and insemination with contaminated semen can also produce infection. Animals which are effected via the respiratory tract, in the pharyngeal area and in the lungs replication of virus occur followed by viremic spread to other organs and tissue before the beginning of the clinical disease. Then the virus distributed throughout the body, and reach in different sites of the body which favor replication of virus like oral cavity, udder, heart, feet, and oro-pharynx [5]. Symptomatically, FMD is characterized by anorexia, fever, blisters on the mucous membranes particularly on mouth, feet, and udder [6]. By using several techniques we can detect FMD virus or viral antigens. In areas where the disease is endemic, routine vaccination is used. On other hand, disease-free countries never vaccinated their livestock but they preferred animal movement restriction, the slaughter of infected and suspected animals when outbreaks of FMD occur. In livestock, it is the most important disease which has a great effect on the economy because FMD causes not only loss of production but also limit the trade of animals both locally and internationally [7]. The occurrence of death is more in the young animals but in adults it having high morbidity and low mortality [8].
Recovered animal take a long time to cover their poor physical condition [9]. An outbreak of FMDV, there is rapid transmission within and between populations because in Vivo replication cycle of the virus is short (4-6 h) and acute onset of shedding (1-3 days) [10-12]. The movement of FMD infected animals should be restricted $[13,14]$. Definition

FMD is defined as an infection of animals of the family Suidae, suborder Ruminantia and order Artiodactyla and Camelus bactrianus with FMDV [15]. It is a highly contagious, acute viral disease of cloven-footed pigs and animals characterized by vesicular eruptions in the mouth, teats and on the feet, anorexia, salivation and fever [16]. FMD is a notifiable livestock disease due to its trans-boundary distribution nature and high infectiousness [17].

\section{Etiology}

Foot and mouth disease virus (FMDV) is the causative agent of FMD of genus Aphthovirus and family Picornaviridae. It is non-enveloped, single-strand RNA virus having $26 \mathrm{~nm}$ in diameter which presents in 7 major serotypes and 60 plus sub serotypes [5]. Geographical distribution of different FMD serotypes (Table 1).

\section{Host species}

FMD is a highly contagious disease. It infects the cloven-footed animals including pigs, cattle, goats, sheep and buffalo. Cloven hoofed wild animals such as antelope, wild pigs, elephant, camelids and deer and also susceptible to FMD. Old world camels may show resistance against the natural infection with some strains. South American camelids like llamas and alpacas are mildly susceptible. The strain of FMD which can infect the deer and wild pigs can also infect cattle. Guinea pigs, rats, mice and armadillos can be infected experimentally [18]. Although cats, dogs and horses can carry the virus on their hairs but are not susceptible to FMD [19]. 
Table 1. Geographical distribution of different FMD serotypes

\begin{tabular}{|c|c|}
\hline Regions & Serotypes \\
\hline Asia & A,O,Asia1 \\
\hline Africa & A,O,C,SAT1,SAT2,SAT3 \\
\hline Europe & A,O,C \\
\hline South America & A,O,C \\
\hline Oceania & FMD free \\
\hline North and Central America & FMD free \\
\hline Caribbean & \\
\hline
\end{tabular}

\section{Carrier state}

Van Bekkum first demonstrated that during the convalescent phase of FMD, live FMDV could be recovered from esophagealpharyngeal fluids of cattle [20]. Carrier state of the virus in dairy cattle can last as long as 3 and a half years. In sheep and goats, the carrier state has also been identified [21]. African buffalo can carry the virus up to 5 years [22]. In esophageal-pharyngeal fluids of the carrier, the titer of virus is low and in individual animal virus not recovered constantly. To detect the carrier animals, the most sensitive method is the isolation of virus from esophageal-pharyngeal fluids but to increase sensitivity RT-PCR are being developed. In the pharynx, the recovered virus probably originates which appears to be the target area for persistent infection in cattle $[20,23]$.

\section{Pathogenesis}

The main route of infection is the respiratory system. Primarily virus multiplies in the mucous membrane of the pharynx and then with the help of blood and lymphatic it transport to secondary multiplication sites such as in and around the mouth, mammary glands and feet [24]. The virus can be found up to 2 years after exposure to infection in cattle and in sheep this duration is 6 months [6]. The virus can also be present in many body fluids like urine, semen, respiratory tract secretions and also in milk prior to the appearance of clinical signs in the animal. In the oral cavity of infected animals, the virus can remain for a long period [1].

Methods of transmission
The main route of infection is the respiratory tract. However, direct inoculation and ingestion of contaminated food have highly participated in the transmission of infection [1]. Transmission can also occur by contact, by mechanical carriage, by aerosols, by humans or vehicles and through animal products [25]. The virus can be recovered from almost all body secretions like tears, saliva, nasal, milk, vaginal, urine, feces, semen and the placenta of an aborted fetus. Temperature, humidity and $\mathrm{PH}$ are the main factors through which virus survive in these body secretions [1]. In temperate or subtropical climates virus can persist in the air for a longer period but not in the dry and hot climate. The direction and speed of the wind are significant factors in determining the rate of airborne spread. In favorable conditions, it is now estimated that the virus can spread by wind-borne as far as 250km [26]. Outbreaks of FMD mostly occur in country frequently during late spring and winter. Occurrence of FMD is lower in hilly then plains area [27, 28]. Etiology, method of transmission, clinical signs and survival rate of FMD (Fig. 1).

\section{Agent}

Common disinfectants having no effect on the virus. It may be found in gross lesions for more than one year to grow only in areas exposed to mechanical trauma or unusual physiological conditions such as feet, the epithelium of the mouth and teats. In young animals, particularly neonates, most of the time virus can cause necrotizing myocarditis and adults may also be infected with some 
strains of this virus like type $\mathrm{O}$ [26]. In severe cases, ventricular fibrillation is the cause of death during heart attacks or dehydration or as a result of different bacterial complications [24]. Principal routes of FMD transmission between susceptible animals (Fig. 2).

\section{Clinical signs}

When vulnerable animals come in contact with infected animals, clinical signs may appear in 3 to 5 days, although, by natural infection, the incubation period may vary from 2 to 14 days. The severity of clinical signs of the disease depends on the exposure dose, age, and breed of the animal, the strain of the virus, the host species and its degree of immunity. FMD causes fever, excessive salivation, depression and the formation of vesicular type lesions on the mucous membrane of the gums, tongue, dental pad and the surface of udder teats, muzzle, coronary band and interdigital spaces [29, 30]. Lesions present on tongue take a few days to heal but which are present on feet and in the nasal cavity may lead to secondary bacterial infection resulting in mucopurulent discharge from the nasal cavity and prolonged lameness [6]. Due to necrotizing myocarditis, young animals may die before showing any vesicles. In lactating cow milk yield also drop due to the formation of vesicles on the skin of teats and udder which leads to mastitis [30]. Clinical signs of FMD (Fig. 3).

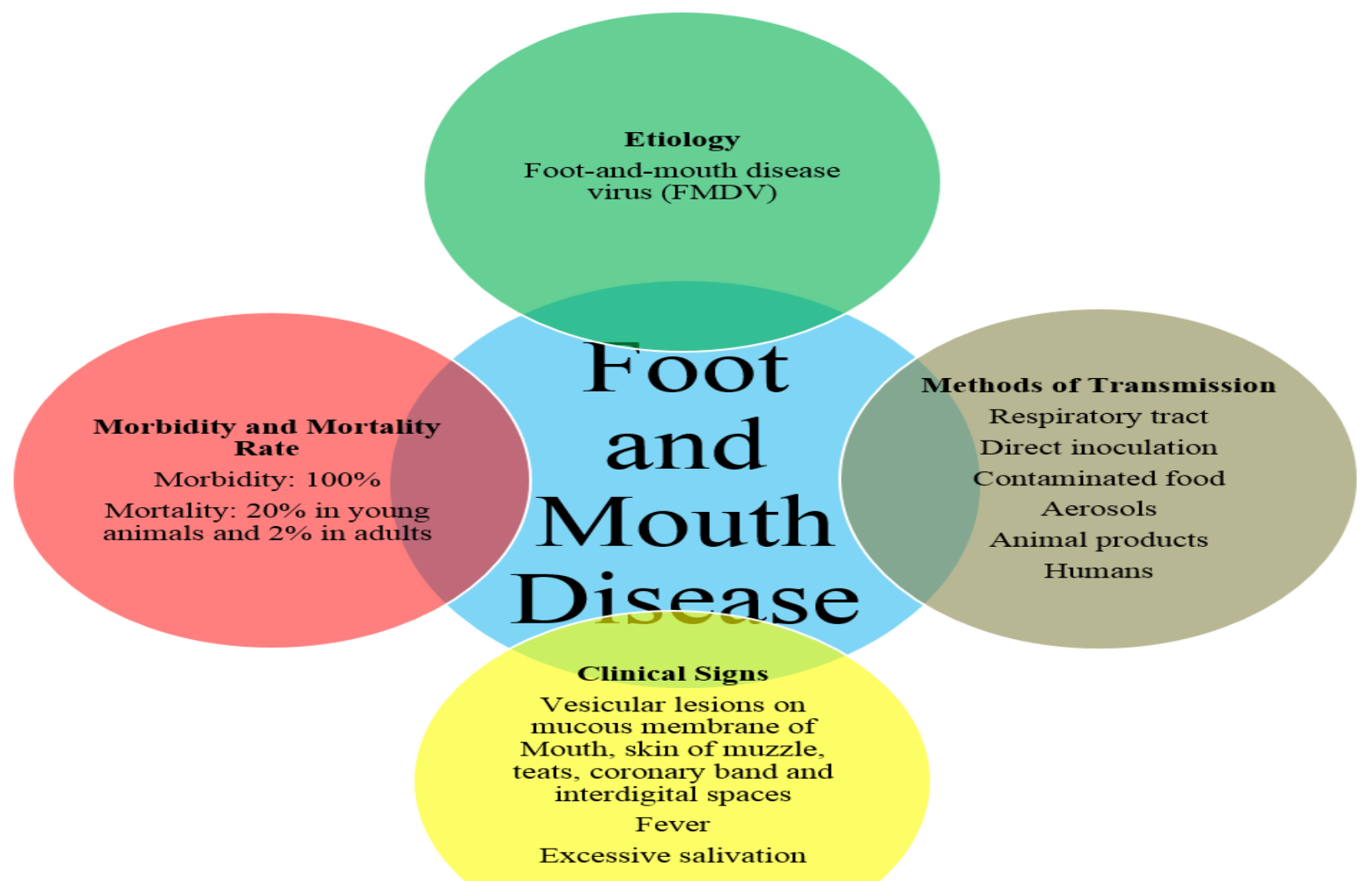

Figure 1. Etiology, method of transmission, clinical signs and survival rate of FMD 


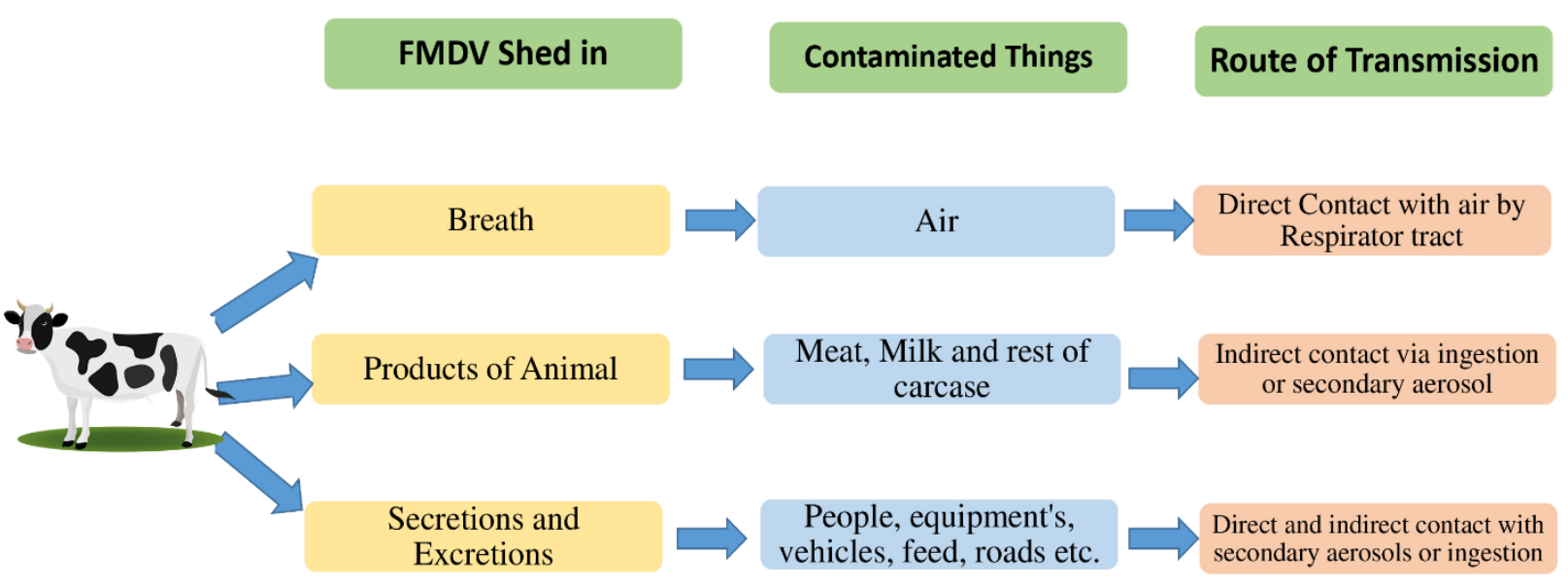

Figure 2. Principal routes of FMD transmission between susceptible animals

\section{Clinical Signs of Foot and Mouth disease in Dairy Cattle}

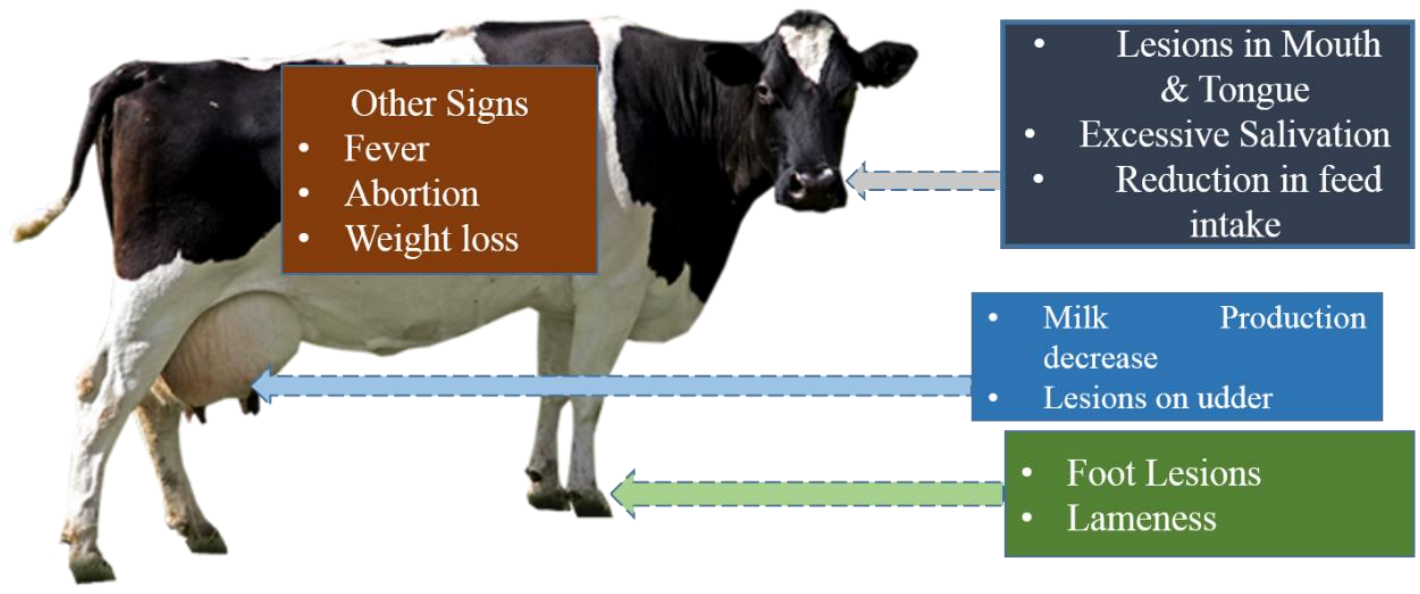

\section{Figure 3. Clinical Signs of FMD in Cattle}

\section{Morbidity and mortality rate}

FMD virus can easily transmit to other animals and about $100 \%$ exposed animals become infected. The morbidity rate in FMD infected animals is $100 \%$. However, the mortality rate is $20 \%$ in young animals and $2 \%$ in adults. The morbidity rate depends on sex, species and status of immunity. Self- recovery is the result of immunity against the serotype of the virus. Mostly, FMD occurs due to one type of virus and immunity remain limited against specific serotype, thus no immunity develops against another serotypes, so in endemic areas, it is the main reason behind occurrence of disease [31]. In most extreme cases, mortality in lambs and 
suckling pigs ranges from $20-75 \%$ and it depends on age. Mortality is high in lower age animals like under 4 weeks of age but it decreases rapidly as animal age increase (more than 4 weeks). Most deaths occur due to slaughter policies that involves all suspected animals during an outbreak in endemic and developed countries [32].

\section{Post mortem finding}

Vesicular lesion and erosion of FMD present on udder, food and mouth. When the vesicles rupture, the formation of the eroded red area and then gray fibrinous covert this part. Color of coting becomes green or yellow then-new epithelium replace this area. Sometimes vesicles are not formed and fluid escape from the epidermis. The appearance of these "Dry" lesions are necrotic instead of vesicular. In the oral cavity of the pig, these Dry lesions are very common [33]. In case, if secondary bacterial infection present, the erosions become ulcerative. Tissues for histopathological examination should contain mucous membrane of oral cavity and skin containing vesicles or fresh erosions. The pancreas, mammary gland and heart should also be included. C. perfringens can also cause pneumonia and respiratory distress in FMD-infected cattle and buffalo [34].

\section{Diagnosis}

Diagnosis of FMD is based on clinical signs and lab findings [35]. For FMD virus detection following techniques are used

\section{Serological tests}

By detection of specific antibody response, the FMDV virus can be diagnosed. Commonly used tests are solid-phase ELIZA (Enzyme Linked Immunosorbent Assay), CFT (Complement Fixation Test), RT-PCR (Reverse Transcription Polymerase Chain Reaction), PCR (Polymerase Chain Reaction) and some non-structural protein antibody tests are also available such as enzyme-linked immune electrotransfer blot assay [36]. For detection of FMD virus antigens and serotype identification preferred procedure is ELIZA [9].

\section{Direct complement fixation test}

Before the development of techniques for virus isolation, Ciuca (1929) show that to detect the FMDV and serotype isolates, a direct complement fixation test could be used [37]. The basic concept of this method was based on virus-antibody complexes bind to the guinea pig-derived complement. In the presence of an anti-sheep RBC antibody, if the binding of the virus with an antibody does not occur, free complement cause the lyses of sheep red blood cells (RBC). FMDV antibodies are serotype-specific, so the identification of FMDV serotypes using the direct complement fixation test was possible [38].

\section{ELISA (Enzyme Linked Immunosorbent} Assay)

For antibody detection ELIZA is the most suitable test [39]. Although some methods that are based on virus isolation or nucleic acid in samples of tissue or the demonstration of FMD viral antigen or culture products is enough for a positive diagnosis. For the detection of FMD viral antigen, the ELISA using type-specific serological reagents is the preferred. For a faster approach to detect viral antigens, Sandwich ELISA is best but it has low sensitivity. Several researches are conducted to developing alternative assay systems that are more rapid for confirmation of clinical diagnosis and these methods can also perform 'Pen side' [40].

\section{RT-PCR (Reverse Transcription Polymerase Chain Reaction):}

For specific detection and high sensitivity, reverse transcription-PCR (RT-PCR) is used to diagnose the Foot-and-mouth disease virus (FMDV). Viral RNA can be detected by this test from different animal samples. This test can also be used for amplifying genome fragments of FMDV in sample material like milk, serum, epithelium and OP samples [41]. 


\section{PCR (Polymerase Chain Reaction):}

For rapid identification of the virus, PCR technique is used. In diagnostic material to amplify the genome fragment of FMD virus RT-PCR (reverse-transcription PCR) can be used. Specific primers are available between each of the 7 serotypes $[25,9]$.

\section{Virus isolation}

With the help of ELIZA vesicular material of FMDV antigen can be detected. But if concentration of virus is too low to be detected by ELIZA, then we need to grow virus on susceptible cell culture [42]. The suspensions that are suspected to FMD virus are inoculated into cell cultures (primary pig kidney cells), incubated at $37^{\circ} \mathrm{C}$ and examined for CPE (cytopathic effect), 24 to 48 hrs. Post infection [43]. Disadvantage of virus isolation technique is unable to grow virus on specific cell type, so if there is absence of virus growth it's not mean that virus is absent in collected sample. Other drawback of this technique are cell culture contamination, confirmation of virus growth by ELIZA and regular maintaining of cell supply [44].

\section{Lab diagnosis}

For diagnosis of FMD in an animal, the sample is collected from vesicular fluid or epithelium of suspected animal. In cattle sample of choice are lesions from buccal mucosa, tissue of tongue, wounds of hoofs or feet. Fluid filled vesicular wound in pig from hoof shall of coronary band, snout and tongue shall be collected [1].

\section{Treatment}

With mild disinfectants, infected animals can be treated topically and some broad-spectrum antibiotics can also be used parentally such as tetracycline [26]. However, the treatment of secondary bacterial infection and proper animal husbandry practices is recommended in endemic countries $[9,19]$.

\section{Control and prevention}

FMD required good preventive measures at the national and international level. FMD free countries should impose strict regulations on animals and animal products import from FMD infected countries [35]. To control the spread of FMD, vaccinations programs can also be used [1]. Import of animals and animal product from FMD infected countries should be banned when the disease is absent in the country. Preventive measures in case of the outbreak are immediate slaughter the infected animals and there should be no contact of the diseased animals with normal animals [7].

\section{Disease outbreaks}

FMD has been a considerable concern to many countries and due to fear of an outbreak of this disease, many research institutes were established. In particular, Lindholm Island in Denmark in 1925, the Insel Reims in Germany in 1909 and the Pirbright laboratory in the United Kingdom in 1924 were specifically opened to study on FMD [45]. In Europe, FMD outbreaks occurred sporadically in the early 20th centuries but their occurrence had shocking consequences [46]. Some in Western Europe, the experience of the outbreak was 104 to 105 per year by the early 1950s [47]. Disease controlled by disinfection, the slaughter of infected animals and inhibition of animal movement, at that time. An inactivated vaccine of FMD was developed in 1930 by Waldmann and colleagues in Germany [48]. The virus was inactivated by formalin aluminum hydroxide gel to produce the vaccine. The virus was collected from collecting epithelium, vesicular fluid and from infecting cattle at the slaughterhouse for the Waldmann vaccine [45]. By this method, the needed amount of vaccine was unable to produce, since only limited numbers of animals could be infected. The virus was produced by infecting bovine tongue epithelium, obtained at the time of slaughter of healthy animals that commercialization of FMD vaccine became a reality and this method was developed by Frenkel [49]. In 
Western Europe, cattle vaccination with this product causes a great reduction in the cases of FMD [47].

\section{De-Population of infected animals}

The killing practice of animals which are suspected and affected by FMD in the herd, or in other herds which has been exposed to FMDV by direct animal to animal contact or by indirect contact likely to cause the transmission of the causal pathogen [50].

\section{Disinfection}

The virus is sensitive to common household bleach of concentration 3\%. It is good to disinfect the properties but not a good choice for the disinfection of footpaths and equipment. Vinegar at 4-5\% dilution can also be used to kill the virus. New disinfectants like Virkos S (surfactant/ organic acid/ per oxygen molecule combination) have a wide spectrum of activity against FMDV and many other germs [51].

\section{Vaccination}

Generally Killed trivalent vaccine (contain C, $\mathrm{A}$ and $\mathrm{O}$ serotypes) are used but It is more common practice to the production of vaccines from the locally isolated virus due to an increase in the number of antigenically dissimilar substrains. In endemic areas, for prophylactive protection, at least two vaccinations are recommended. The current FMD vaccine protects for 6 months. In 21-28 days vaccinated animals attained peak antibody response. Vaccination can also be used to protect specific animals [30]. During an outbreak, prevention of FMD from spreading can be done with the help of emergency vaccinations. There is continuous development of new vaccines but it is labor and difficult to develop a new vaccine whenever a new virus appears $[52,53,54]$. Therefore, many kinds of research have been conducted to develop advanced vaccines that can respond to evolving versions of the virus $[55,56]$. Current problems with FMD vaccines include antigens losses during the process of purification, unable to maintain the antibodies, low immunogenicity and narrow protection range of the antigens [57].

\section{Economic impact of FMD}

FMD is a highly contagious Transboundary animal disease which effects the clovenhoofed animals. Due to this character, the virus of FMD causes severe economic loss by restrictions of export trade and high morbidity. There is a rapid transmission of FMD within and between a wide range of susceptible host species, so this is a threat to small-scale farmers as well as multinational livestock industries $[58,59]$. In many highincome countries, FMD has been eradicated but it is still present in middle and lowincome countries [60]. FMD has low mortality but significant losses of production that may lead to important economic losses [61]. Although research has been conducted to understand the impact of FMD virus [62, 63]. Previous studies show that the introduction of FMD virus in FMD free countries cause a severe impact on national economies [64]. The economic impact of FMD can be divided into two components, direct impact and indirect impact. The direct impacts include reduced livestock growth, reduced milk production, problems with fertility, mortality in young stock and indirect impact includes additional cost like vaccination costs and movement control [65, 33]. Some governments have been considered the potential role of FMD in bioterrorism due to the relative case with which from outbreaks in endemic countries, highly contagious material can be obtained and severe economic losses in FMD free countries [66, 67]. In most parts of Africa, FMD is enzootic and some other countries have managed tools to control the disease $[68,69,70]$. A high rate of contact among animals at commercial markets and Extensive movement of livestock in watering points and communal grazing areas can cause the incidence of disease $[64,71,72]$.

\section{Conclusion}


FMD is distributed all over the world. This disease having great economic importance because it not only reduce production but also restricts the trading of animals both locally and internationally. So the following points are recommended on the base of the above conclusions. During the outbreak of FMD, restrict the movement of the animal both across national and international boundaries to prevent the spread of the virus. Proper disposal of manure and dead animals. Government should regularly monitor the occurrence of an outbreak and should take necessary steps as soon as possible. In exiting heard, introduction of new animals should controlled. Controls on movement of livestock, vehicles and equipment's are necessary. Key elements of effective disease management are information on the epidemiology and rapid diagnosis. Highly infected areas should be considered during control program. Periodic and Regular mass vaccination of animals (2 times in a year is compulsory).

\section{Authors' contributions}

Conceived the idea: I Rasheed, MM Hassan, Corrections: M Asad \& A Tehseen, Proof Reading: G Kaukab \& S Aamir, Correspondence: A Azeem, Wrote the Paper: A Azeem.

\section{References}

1. Hirsh CD, MacLauchlan NJ \& Walner RL (2004). Veterinary Microbiology. Black Well Sci 2: 341.

2. Grubman MJ \& Baxt B (2004). Foot-andmouth disease. Clin Microbiol Rev 17: 465-493.

3. You SH, Jo HE, Choi JH, Ko MK, Shin SH, Lee MJ, Kim SM, Kim B \& Park JH (2019). Evaluation of novel inactivated vaccine for type $\mathrm{C}$ foot-and-mouth disease in cattle and pigs. Vet Microbiol 234: 4450.

4. Ding YZ, Liu YS, Zhou JH, Chen HT, Wei G, Ma LN \& Zhang J (2011). A highly sensitive detection for foot-and-mouth disease virus by gold nanopariticle improved immuno-PCR. Virol J 8(1): 148.

5. Admassu (2015). Review on foot $\&$ mouth disease: Distribution \& economic significance. Acad J of Anim Dise 4: 160169.

6. Knipe DA \& Howely DM (2001). Fields Virology. 4th ed. Welter Kluwer Health; London, pp 521-527.

7. James AD \& Rushton J (2002). The economics of foot \& mouth disease. Revue Scientif Et Tech-Off Inter Des Epizooties 21: 637-641.

8. Mazengia (2010). Incidence of foot \& mouth disease $\&$ its effect on milk yield in dairy cattle at \&assa dairy farm, Northwest Ethiopia. Agric Biol JN Am 1: 969-973.

9. Stear M (2005). OIE Manual of Diagnostic Tests \& Vaccines for Terrestrial Animals (Mammals, Birds \& Bees). 5th Ed. Volumes 1 \& 2. World Organization for Animal Health 2004. ISBN 929044622 6.€ 140. Parasitol 130: 727-727.

10. Grubman MJ \& Baxt B (2004). Foot-andmouth disease. Clin Microbiol Rev 17: 465-493.

11. Grau FR, Schroeder ME, Mulhern EL, McIntosh MT \& Bounpheng MA (2015). Detection of African swine fever classical swine fever and foot-and-mouth disease viruses in swine oral fluids by multiplex reverse transcription real-time polymerase chain reaction. J Vet Diagn Invest 27: 140-149.

12. Donaldson AI, Gibson CF, Oliver R, Hamblin C \& Kitching RP (1987). Infection of cattle by airborne foot-andmouth disease virus: minimal doses with O1 and SAT 2 strains. Res Vet Sci 43: 339346.

13. Brooksby J (1958). The virus of foot-andmouth disease. In Smith K and Lauffer M (eds), Advances in Virus Research 5: 1-37.

14. Jaworski JP, Sala JM \& Capozzo A (2018). Bovine leukemia virus infection in adult cows does not interfere with footand-mouth disease vaccination. Int. J. Dairy Sci 101(12): 11247-11250. 
15. OIE (2015). Terrestrial animal health code. Volume II: Recommendations applicable to OIE listed disease and other diseases of importance to international trade. 24th ed. World Organization for animal health (OIE), Paris, France pp 455 477.

16. Quinn PJ, Markey BK, Carter ME \& Leonard FC (2002). Veterinary Microbiology and Microbial disease. USA, Black well publisher. 405.

17. Knight-Jones TJD \& Rushton J (2013). The economic impacts of foot and mouth disease-What are they, how big are they and where do they occur?. Prev. Vet. Med 112(3-4): 161-173.

18. OIE (2011). Terrestrial Code Twentieth edition Chapter. 4.13.

19. Barry B \& B Richard (2010). Foot and Mouth Disease Veterinary Bulletin 1(2).

20. Van Bekkum JG, Frenkel HS, Frederiks HHJ \& Frenkel S (1959). Observations on the carrier state of cattle exposed to footand-mouth disease virus. Tijdschr. Diergeneeskd, 84: 1159-1164.

21. Alexandersen $S$, Zhang Z \& Donaldson AI (2002). Aspects of the persistence of footand-mouth disease virus in animals - the carrier problem. Microbes Infect 4(10): 1099-1110.

22. Borrego B, Camarero JA, Mateu MG \& Domingo E (1995). A highly divergent antigenic site of foot-and-mouth disease virus retains its immunodominance. Viral Immunol 8(1): 11-18.

23. Murphy MLP, Forsyth MA, Belsham GJ \& Salt JS (1999). Localization of foot-andmouth disease virus RNA by in situ hybridization within bovine tissues. Virus Res 62(1): 67-76.

24. Lefevere CP (2010). Infectious \& parasitic disease of livestock. Paris.

25. Quinnand P \& Markey B (2003). Concise Review of Veterinary Microbiology. Blackwell Publishing.

26. Radostits OM, Blood DC \& Gay CC (2007). A Text Book of the Disease of Cattle, Sheep, Goats, Pigs \& Horses. 8th ed. Balliere Tindall; London.
27. Abubakar M, Arshed MJ, Gonzales J, Ferrari G, Hussain M \& Ali Q (2015.) An appraisal on the occurrence of foot-andmouth disease virus serotypes in cattle and buffaloes, Pakistan. Arc 160(6): 15611564.

28. Hussain A, Abubakar M, Shah H, Arshed MJ, Batool S \& Afzal M (2019). Impact assessment of ring vaccination to control economic losses of Foot and Mouth Disease in Pakistan. Pak. J. Agric 56(4).

29. Blowey RW \& Weaver AD (2003). Color atlas of diseases $\&$ disorders of cattle. 2 nd ed. Mosby Publisher.

30. Hirsh CD \& Zee CY (1999). Veterinary Microbiology. 2nd ed. Black Wall Science; USA.

31. Chang H, Ma Y, Lin T, Cong G, Du J \& Ma J (2013). Foot-and-mouth disease virus carrier status in Bos grunniens yaks. Virol J 10(1): 81.

32. Mitiku T, Garedew L, Zemene M, Dagnaw M, Admassu B \& Getaneh G (2016). A review on foot and mouth disease and its current status in Ethiopia. Res 8(8): 2.

33. Fiebre A (2018). Foot and Mouth Disease (FMD)https://aglearn.usda.gov/customco ntent/APHIS/Disposal/FAD/images/fmdF actsheet.pdf assessed on 22/11/2018.

34. Elgioushy M, Rizk MA, El-Adl M, Elhadidy M \& El-Khodery S (2019). The first molecular detection of Clostridium perfringens from pneumonic cases associated with foot and mouth disease in cattle and buffalo in Egypt. Trop Anim Health Pro 51(4): 847-852.

35. Aitken ID (2007). Disease of sheep. 4th ed. Blackwell Publishing; USA.

36. Hughes GJ, Mioulet V, Kitching RP, Alexandersen $\mathrm{S}$, Donaldson AI \& Woolhouse MEJ (2002). Foot-\&-mouth disease virus infection of sheep: implications for diagnosis \& control. Vet Rec 150: 724-727.

37. Bachrach HL (1968). Foot-and-mouth disease. Annu Rev Microbiol 22(1): 201244. 
38. Traub E (1983). Foot-and-mouth disease typing with the complement-fixation test first communication.

39. Birhanu T, Mezgebu E, Ejeta E, Gizachew A \& Nekemte E (2015). Review on Diagnostic Techniques of Bovine Tuberculosis in Ethiopia. Rep Opinion 7: 7-14.

40. Verma A, Kumar A, Mahima M \& Sahzad S (2012). Epidemiology and diagnosis of foot-and- mouth disease: A review. Indian J Anim Sci 82: 543-551.

41. Sáiz M, Diana B, Blanco E, Núñez JI, Fernández R \& Sánchez-Vizcaíno JM (2003). Detection of foot-and-mouth disease virus from culture and clinical samples by reverse transcription-PCR coupled to restriction enzyme and sequence analysis. Vet Res 34(1): 105-117.

42. Stear MJ (2005). OIE Manual of Diagnostic Tests and Vaccines for Terrestrial Animals (Mammals, Birds and Bees) 5th Edn. Volumes 1 \& 2. World Organization for Animal Health 2004. ISBN 929044622 6.€ 140. Parasitology 130(6): 727-727.

43. Kitching R \& Hughes G (2002). Clinical variation in foot $\&$ mouth disease: sheep \& goats. Rev Sci 21: 505-510.

44. Jamal SM. \& Belsham GJ (2013). Footand-mouth disease: past, present and future. Vet Res 44(1): 116.

45. Brooksby JB (1982). Portraits of viruses: foot-and-mouth disease virus. Intervirology 18: 1-23.

46. Barteling SJ \& Vreeswijk J (1991). Developments in foot-and-mouth disease vaccines. Vaccine 9(2): 75-88.

47. Brown F (1992). New approaches to vaccination against foot-and-mouth disease. Vaccine 10: 1022-1026.

48. Waldmann O, Kobe K \& Pyl G (1937). Die aktive immunisierung des rindes gegen Maul-und Klauenseuche mittels formolimpfstoff. Zentbl Bakteriol Parasitenkd Infektkhrankh 138: 401-412.

49. Frenkel HS (1947). La culture de virus de la fievre aphteuse sur l'epithelium de la langue des bovides. Bull Off Int Epiz 28: 155-162.

50. OIE (2014). http://www.oie.int/index.php?id=169 \& $\mathrm{L}=0$ \&htmfile $=$ glossaire.htm. Accessed, 22 June.

51. Depa PM, Dimri U, Sharma MC \& Tiwari $R$ (2012). Update on epidemiology and control of Foot and Mouth Disease-A menace to international trade and global animal enterprise. Vet World 5(11).

52. Mahapatra M \& Parida S (2018). Foot and mouth disease vaccine strain selection: current approaches and future perspectives. Expert Rev Vaccines 17(7): 577-591.

53. Mahapatra M, Upadhyaya S, Aviso S, Babu A, Hutchings G \& Parida S (2017). Selection of vaccine strains for serotype $\mathrm{O}$ foot-and-mouth disease viruses (20072012) circulating in Southeast Asia, East Asia and Far East. Vaccine 35(51): $7147-$ 7153.

54. Ko MK, Jo HE, Choi JH, You SH, Shin SH, Jo H, Lee MJ, Kim SM, Kim B \& Park JH (2019). Chimeric vaccine strain of type $\mathrm{O}$ foot-and-mouth disease elicits a strong immune response in pigs against ME-SA and SEA topotypes. Vet 229: 124-129.

55. Caridi F, Vázquez-Calvo Á, Borrego B, McCullough K, Summerfield A, Sobrino F \& Martín-Acebes MA (2017). Preserved immunogenicity of an inactivated vaccine based on foot-and-mouth disease virus particles with improved stability. Vet 203: 275-279.

56. Park JN, Ko MK, Kim RH, Park ME, Lee SY, Yoon JE, Choi JH, You SH, Park JW, Lee KN \& Chun JE (2016). Construction of stabilized and tagged foot-and-mouth disease virus. J Virol Methods 237: 187191.

57. Mahapatra M, Upadhyaya S, Aviso S, Babu A, Hutchings G \& Parida S (2017). Selection of vaccine strains for serotype $\mathrm{O}$ foot-and-mouth disease viruses (20072012) circulating in Southeast Asia, East Asia and Far East. Vaccine 35(51): 71477153. 
58. Arzt J, White WR, Thomsen BV \& Brown CC (2010). Agricultural diseases on the move early in the third millennium. Vet Pathol 47(1): 15-27.

59. Pacheco JM, Stenfeldt C, Rodriguez LL \& Arzt J (2016). Infection dynamics of footand-mouth disease virus in cattle following intranasopharyngeal inoculation or contact exposure. J Comp Pathol 155(4): 314-325.

60. Robinson TP, Thornton PK, Franceschini G, Kruska RL, Chiozza F, Notenbaert AMO, Cecchi G, Herrero MT, Epprecht M, Fritz S \& You L (2011). Global livestock production systems. FAO and ILRI.

61. Di Nardo A, Knowles NJ \& Paton DJ (2011). Combining livestock trade patterns with phylogenetics to help understand the spread of foot and mouth disease in sub-Saharan Africa, the Middle East and Southeast Asia. Rev Off Int Epizoot 30(1): 63.

62. Lyons NA, Alexander N, Stärk KD, Dulu TD, Sumption KJ, James AD, Rushton J \& Fine PE (2015). Impact of foot-and-mouth disease on milk production on a largescale dairy farm in Kenya. Prev Vet Med 120(2): 177-186.

63. Duchatel F, Bronsvoort BMDC \& Lycett SJ (2019). Phylogeographic analysis and identification of factors impacting the diffusion of Foot-and-Mouth disease virus in Africa. Front Ecol Evol 7: 371.

64. Sissay M, Delesa D and Getachew MD (2017). Serotyping and Molecular Characterization of Foot and Mouth Disease of Cattle in Central Ethiopia (Doctoral dissertation, Harmaya University).
65. Paton DJ, Gubbins S \& King DP (2018). Understanding the transmission of footand-mouth disease virus at different scales. Curr Opin Virol 28: 85-91.

66. Farsang A, Frentzel H, Kulcsár G \& Soós $\mathrm{T}$ (2013). Control of the deliberate spread of foot-and-mouth disease virus. Biosecur Bioterror 11(S1): S115-S122.

67. Knight-Jones TJD, Robinson L, Charleston B, Rodriguez LL, Gay CG, Sumption, K.J. \& Vosloo W (2016). Global Foot-and-Mouth Disease Research Update and Gap Analysis: 2Epidemiology, Wildlife and Economics. Transbound Emerg Dis 63: 14-29.

68. Sahle M (2004). An epidemiological study on the genetic relationships of foot and mouth disease viruses in east Africa (Doctoral dissertation, University of Pretoria).

69. Vosloo W, Bastos ADS, Sangare O, Hargreaves SK \& Thomson GR (2002). Review of the status and control of foot and mouth disease in sub-Saharan Africa. Rev Sci Tech 21(3): 437-445.

70. Naranjo J \& Cosivi O (2013). Elimination of foot-and-mouth disease in South America: lessons and challenges. Pahilos $T$ R Soc B 368(1623): 20120381.

71. Ayelet G, Mahapatra M, Gelaye E, Egziabher BG, Rufeal T, Sahle M, Ferris NP, Wadsworth J, Hutchings GH \& Knowles NJ (2009). Genetic characterization of foot-and-mouth disease viruses, Ethiopia, 1981-2007. Emerg 15(9): 1409.

72. Wondwossen A \& Tariku S (2000). The status of FMD in Ethiopia: a growing concern. Prev Vet Med 1(2): 1-5. 